\title{
Educators' Perceptions of School-Based Factors that Impact Their Effectiveness in Working with Students with Challenging Behaviors: A Pilot Investigation
}

\author{
Lyndal M. Bullock ${ }^{1, *}$, Stacie M. Zolkoski², Mandy E. Lusk ${ }^{3} \&$ Katrina A. Hovey ${ }^{4}$ \\ ${ }^{1}$ University of North Texas, Denton, USA \\ ${ }^{2}$ University of Texas at Tyler, USA \\ ${ }^{3}$ Clayton State University, Atlanta, GA, USA \\ ${ }^{4}$ Western Oregon University, Manmouth, USA \\ *Correspondence: University of North Texas, 2617 Picadilly Lane, Denton, TX 76209-8656, USA. Tel: \\ 1-940-367-3221. E-mail: Bullock.Lyndal@gmail.com
}

Received: June 3, 2017

Accepted: June 14, 2017 Online Published: June 27, 2017

doi:10.5430/wje.v7n3p92

URL: https://doi.org/10.5430/wje.v7n3p92

\begin{abstract}
The purpose of the present study was to complete a pilot investigation to learn more about how educators who have had experience working with students with challenging behaviors perceive school-related challenges impacting their effectiveness. Further, information was gleaned as to what educators believe to be major issues faced in their educational roles. More specifically, the study provides a glimpse of educators' perceptions of their preparation programs, strengths and weaknesses of the leadership in their schools, leaderships' encouragement to collaborate with others in their educational communities, and major problems they face in educating students
\end{abstract}

Keywords: administrative leadership; challenging behaviors; collaboration; educator perceptions; problems teachers face

\section{Introduction}

Schools are complex entities designed to prepare future generations to become successful and productive citizens. Although there are numerous individuals within the confines of schools who make significant contributions to children and youth (e.g., counselors, custodians, food workers), it is the teachers and administrators who control much of the decision-making about what happens in the school. There are significant reports in the literature regarding the value of providing a school climate designed to maximize student learning (e.g., Center for Public Education, 2005; Paolini, 2015; Pennsylvania Partnerships for Children, 2011; Rand Corporation, 2017). Further, collaboration with other school-based professionals, parents, and community leaders also impact student learning. In the quest fora better understanding of the impactors on student learning, we instigated a pilot study to examine teachers' perceptions about their professional preparation, educators' perceptions about their administrators' leadership, teachers' perceptions of collaboration in their school, and to learn more about the major problems faced in their current assignments.

\subsection{Teachers' Perceptions about Their Professional Preparation}

Since teachers wield a critical role in the lives of the nation's students, it is important they have exemplary preparation to effectively assume their respective roles. Numerous published works examine various issues related to how teachers perceive their professional preparation (e.g., Allen, 2003; Beijaard, Verloop \& Vermunt, 2000; Lingam, 2012; Phillips, 2013; Sharma, 2005; Yates, 2007) in areas such as (a) understanding various assessment techniques, (b) maintaining adequate classroom discipline, (c) utilizing appropriate curriculum, (d) working with children and families from culturally and linguistically diverse backgrounds, and (e) collaboratively working with coworkers and parents (Lingam, 2012). Undoubtedly, the way educators perceive their personal competence influences their perceptions about the school leadership (Powers, 2012). 


\subsection{Educators' Perceptions about Their Administrators' Leadership}

The role of school administrators has been a point of discussion in the literature for many years (e.g., Coleman, 2005; Ismail, 2012; Richardson, Lane, \& Flanigan, 1996). Is the primary role of the school administrator a manager, an instructional leader, or a disciplinarian? In reality, the school administrator is the key to all aspects of the school, in that, she significantly influences the attitudes of the teachers, parents, and community, as well as children. The administrator is expected to encourage collaboration and engage in shared decision-making. Further, as an instructional leader, the administrator is the one who cultivates a culture conducive to providing quality instruction, and establishes expectations related to curriculum and instruction while ensuring all necessary resources are available to support the goals of the school. Consequently, the school administrations' leadership sets the precedence for establishing a nurturing environment whereby all personnel feel valued and students are ensured an education that best meets their learning and behavioral needs. The effectiveness of the school is powerfully influenced by how teachers feel about their administrators' leadership (e.g., Hardman, 2011; Ismail, 2012; Kursunoglu \& Tanriogen, 2009; LoVette \& Karst, n.d; McCann, 2011; Mercurius, n.d.; Methner, 2013; National Association of Elementary School Principals, 2013; Powers, 2012; Richardson et al., 1996; Sipes, 2014).

\subsection{Teachers' Perception of the Collaboration in Their School}

It is often implied that teachers, although surrounded by many people, work in isolation (e.g., grading papers, preparing lesson plans, generating reports, attending formal meetings to examine student progress). Professional learning communities (a.k.a collaboration communities), in recent years, have become a popular avenue to provide teacher support and improve the achievement of students (DuFour, DuFour, Eaker, \& Many, 2010; Goldstein, 2015). The value of collaboration among all school personnel has been the focus of numerous reports (e.g., Brook, Sawyer, \& Rimm-Kaufman, 2007; Hagelman, 2013; Iordanides, Lazaridou, \& Babaliki, 2011; Waldron \& Mcleskey, 2010). Again, the administrator is the key in establishing and ensuring the effectiveness of collaborative efforts throughout the school environment (Somech \& Wenderow, 2006).

\subsection{Teachers' Report of Major Problems Faced in Their Current Assignments}

A wide range of professional development opportunities are available to assist educators in becoming well versed in a myriad of curricular and technological innovations applicable to the classroom. Regardless of the innovations, when working with children and youth, it remains necessary for teachers to be sensitive to the individual needs of students. Teaching in today's schools is a Herculean task! Teachers face what may be viewed as almost an impossible challenge given the numerous responsibilities to which they must respond. Research studies illustrate the array of problems noted by teachers: (a) support and facilitate opportunities to collaborate with other school personnel (Goodwin, 2012; Manna, 2015), (b) classroom management and discipline (al-amarat, 2011; Goodwin, 2012; Hamdallah, 2005; Hang, 2011; Manna, 2015; Moore, 2012), (c) curriculum constraints (Goodwin, 2012), and (d) student and parent apathy (Moore, 2012). Moore also listed specific problems such as text messaging and other cell phone usage, inappropriate use of computers, student fatigue, lack of respect for authority, and limited options for teachers when disciplining.

A commonly cited challenge faced by teachers is the vast range of students in their classrooms (The Take Away, 2015). For example, students with disabilities (e.g., autism, behaviorally challenged, medically fragile) require significant amounts of individual attention and unique planning. A more recent challenge is the increasing numbers of English language learners (ELL) who must be accommodated to ensure they understand and can respond to instruction. Demographic changes in the United States of America (USA) indicate sustained increases in the number of ELL students, especially in the Hispanic population, and are creating a paradigm shift in teaching practices for educators (Shrestha \& Heisler, 2011). According to the National Center for Education Statistics (2015), ELL students represent $21 \%$ of the K-12 population in the USA; however, projections indicate that by the year 2030, ELL students will comprise $40 \%$ of the student body in USA schools (Guglielmi, 2008; Watkins \& Lindahl, 2010).

On a daily basis, educators have the opportunity to make significant contributions to the present and future of students. One of the major opportunities in schools is related to how to address the needs of children/youth who present challenging behaviors. As an initial step, it is important to understand more about the perceptions of educators regarding various aspects of the school environment. For this study, students with challenging behaviors refer to those who qualified for special education services because of internalized or externalized behavioral issues regardless of the setting in which services were provided. To assist in meeting the needs of students, a myriad of unique expectations must be met, some of which are addressed in the current study. 


\section{Purpose}

The purpose of the present study was to complete a pilot investigation to learn more about how educators who have had experience working with students with challenging behaviors perceive school-related challenges impacting their effectiveness. Further, we wanted to ascertain whether a more extensive nationwide investigation might be of value. Four questions guided the study.

1- How do educators perceive the effectiveness of their professional preparation programs?

2- How do educators perceive their administrators' leadership regarding services for students with challenging behaviors?

3- How do educators perceive the collaboration that takes place in their schools' environment?

4- What do educators believe to be the major problems in their current assignments?

\section{Procedures}

\subsection{Instrumentation}

After completing a comprehensive review of literature, a survey instrument was developed taking into consideration relevant issues mentioned by different researchers. In addition to selected demographic information, the final version of the instrument consisted of 20 items designed to obtain educators' perceptions regarding school-related challenges which impact their effectiveness. For the initial section of the survey, respondents were asked to respond on a Likert scale with options of "poor", "inadequate", "adequate", "excellent", and "exemplary". Finally, respondents were given an opportunity to rank the five most pressing problems associated with their school assignment. The draft version was submitted to a nucleus of teachers, administrators, and higher education personnel with instructions to examine the items for content validity, clarity, and relevance of options provided (Oppenheim, 1992). Respondents were also provided opportunity to suggest modifications. Several relevant clarifying suggestions were forthcoming. Once revisions were made the instrument was resubmitted to the original reviewers until consensus was reached as to what resulted in the final version of the survey instrument.

\subsection{Respondent Selection}

The perceptions of general and special educators with representation from each the four census regions of the USA (US Census, 2016) who had experience working with students with challenging behaviors were obtained through an online survey using snowball sampling through face-to-face contact and emails (Heckathorn, 1997). To obtain a cross-section of potential study participants, 10 colleagues working in higher education settings in each of the four census regions (total of 40) were contacted whose professional roles would allow them to facilitate the dissemination of the survey form to individuals who, to their personal knowledge, had experience in working with students with challenging behaviors whether they were currently working as a teacher or in another role. Colleagues were asked if they would be willing to disseminate the instrument to educators who met the study criteria delineated above with whom they were familiar in their respective geographic regions. Once colleagues agreed to assist, they were given a personalized invitation to be sent to the potential participants along with the electronic link by which to access the survey instrument. Since it is unknown how many invitations were disseminated, only the number of respondents is known.

\section{Results}

Descriptive statistics were used to examine the sample and the subgroups within the sample. Descriptive data analysis measured frequencies of responses to understand respondents' perceptions of their professional preparation, how they viewed their administrators' leadership in the school, and the collaborative efforts among professionals in the school(s) in which they were associated. Only completed surveys were utilized in the analysis.

\subsection{Demographic Information}

The sample consisted of 172 individuals, representative of all four census regions of the USA, who had experience working with students with challenging behaviors: males $(n=40 ; 23.3 \%)$, females $(n=130 ; 75.6 \%)$, and other/prefer not to answer $(\mathrm{n}=2 ; 1.1 \%)$. The racial/ ethnic makeup of the respondents was White $(\mathrm{n}=138 ; 80.2 \%)$, Hispanic or Latino $(\mathrm{n}=17 ; 9.9 \%)$, Black or African American $(\mathrm{n}=7 ; 4.1 \%)$, Asian $(\mathrm{n}=3 ; 1.7 \%)$, American Indian or Alaskan native $(\mathrm{n}=3 ; 1.7 \%)$, Native Hawaiian or Pacific Islander $(\mathrm{n}=1 ; 0.6 \%)$, and other $(\mathrm{n}=3 ; 1.7 \%)$.

Respondents reported working in schools located in a variety of settings: rural $(\mathrm{n}=22 ; 12.8 \%)$, suburban $(\mathrm{n}=105$; 
$61.0 \%)$, and urban $(\mathrm{n}=45 ; 26.2 \%)$. Although all respondents had experience working with children/youth with challenging behaviors, their current roles in education varied: special education $(\mathrm{n}=79 ; 46.0 \%)$, general education $(\mathrm{n}$ $=52 ; 30.2 \%)$, general and special education $(n=31 ; 18 \%)$, and other areas of education (i.e., administration, related services, and counseling; $\mathrm{n}=10 ; 5.8 \%$ ). They were also asked the number of years' experience they had teaching children and adolescents in various settings. The average years teaching children and youth in special and general education were similar with the average being 6.4 years teaching special education and 6.1 years teaching general education. Participants reported having fewer years teaching experience in general education inclusion classrooms (average of 2.7 years).

As noted earlier, 172 respondents completed the survey on which they rated the items using the designated five-point scale. Data provided in Table 1 show the means of respondents' perceptions based on the 20 -item survey. The survey items have been arranged by mean ratings which correspond to three of the research questions: perceptions about professional preparation, perceptions about administrators' leadership, and perceptions related to collaboration in the respondents' schools. The fourth question of the survey was to learn about the most pressing problems educators face in their work with students with challenging behaviors.

Table 1. Study Respondents' Perspectives about Professional Preparation, Administrators' Leadership, and Collaboration

\begin{tabular}{|c|c|c|}
\hline Perceptions Regarding Professional Preparation & $M$ & $S D$ \\
\hline I would rate my effectiveness in educating students with challenging behaviors as ... & 3.62 & 678 \\
\hline $\begin{array}{l}\text { I would rate my professional preparation in the implementation of classroom behavioral } \\
\text { management strategies as ... }\end{array}$ & 3.45 & .993 \\
\hline $\begin{array}{l}\text { I would rate my teacher preparation program in working with students with challenging } \\
\text { behaviors as ... }\end{array}$ & 3.24 & 1.097 \\
\hline Perceptions Regarding Administrators' Leadership & $M$ & $S D$ \\
\hline I feel the support given me by my administrator(s) is ... & 3.25 & 1.055 \\
\hline $\begin{array}{l}\text { The leadership skills of my administrator(s) during individual education planning (IEP) meetings } \\
\text { are ... }\end{array}$ & 3.22 & 1.080 \\
\hline $\begin{array}{l}\text { The support provided by my administrator as I work with students with challenging behaviors } \\
\text { is ... }\end{array}$ & 3.19 & 1.124 \\
\hline Advocacy by my administrators for students with challenging behaviors is ... & 3.13 & 1.043 \\
\hline In my school, administrators' understanding for students with challenging behaviors is ... & 3.08 & 1.157 \\
\hline $\begin{array}{l}\text { I would rate my administrators' involvement in ensuring quality programming for students with } \\
\text { challenging behaviors as ... }\end{array}$ & 3.03 & 1.095 \\
\hline The time provided for me to conduct parent conferences is & 3.03 & .994 \\
\hline The number of students given me by my administrator(s) is ... & 2.85 & .985 \\
\hline The resources provided to support my instructional program is & 2.88 & 1.019 \\
\hline The time available to effectively teach my students is... & 2.80 & .983 \\
\hline $\begin{array}{l}\text { In my school, the time allotted to collaborate with other professionals regarding students with } \\
\text { challenging behaviors is ... }\end{array}$ & 2.49 & .970 \\
\hline The time I have during the day to complete all paper work is ... & 1.89 & .827 \\
\hline Perceptions Related to Collaboration & $M$ & $S D$ \\
\hline In my school, collaboration with fellow educators regarding students with whom I work is & 3.40 & .953 \\
\hline In my school, collaboration with para-educators who work in my classroom is . & 3.33 & 1.075 \\
\hline In my school, communication between teachers and administrators is ... & 3.27 & .936 \\
\hline In my school, collaboration between special education teachers and parents is ... & 3.17 & .888 \\
\hline In my school, collaboration between general education teachers and parents is ... & 3.10 & .831 \\
\hline
\end{tabular}




\subsection{Perceptions Regarding Professional Preparation}

The intent of items falling into the category of professional preparation was to examine how respondents viewed their preparation to effectively work with students with challenging behaviors. As noted in Table 1, respondents rated their effectiveness (a) in educating students with challenging behaviors as slightly above the mean $(M=3.62$; $S D$.678), (b) in the implementation of classroom behavioral management (M = 3.45; SD .993), and (c) of their teacher preparation programs in preparing them to work with students with challenging behaviors $(M=3.24 ; S D$ 1.097).

\subsection{Perceptions Regarding Administrators' Leadership}

Of the twelve items related directly to the administrators' leadership, means ranged from 3.25 and 1.89 with standard deviations of 1.055 and .827 respectively. In general, data indicate that respondents tended to view their administrators' leadership as adequate and their perception of support provided by the administrator as the highest $(M=3.25 ; S D$ 1.055). Respondents indicated support by administrators as they work with students with challenging behaviors $(M=3.19 ; S D$ 1.124). Among the lowest mean ratings were items related to the time allocated in the school day for certain tasks to be completed (i.e., paper work $[M=1.89 ; S D .827]$, collaboration $[M=2.49$; $S D$.970], and time available to effectively teach students $[M=2.80 ; S D .983])$.

\subsection{Perceptions Related to Collaboration}

As evidenced in Table 1, all items related to collaboration were rated as slightly above the mean. Based on the data, respondents believed the collaboration among colleagues was adequate with the highest rating given to collaboration with fellow educators regarding students with whom they work $(M=3.40 ; S D .953)$. Collaboration between general education teachers and parents had the lowest rating $(M=3.10 ; S D .831)$.

\subsection{Most Pressing Issues}

Research question four was designed to obtain a better understanding of the issues faced by teachers who work with children and youth with challenging behaviors. The study respondents were asked to select what they perceived to be the five most pressing issues faced in their current positions (see Table 2). Overall, too much paperwork was ranked as the number one problem with $133(77.33 \%)$ respondents ranking it within their top five problems and 48 ranking paperwork as their biggest issue.

Table 2. Study Respondents' Perceptions of Pressing Issues

\begin{tabular}{|c|c|c|c|c|c|c|c|}
\hline \multirow{2}{*}{ Problems Identified by Respondents } & \multicolumn{5}{|c|}{$\begin{array}{c}\text { Rank Order of Problems } \\
\text { Stated }\end{array}$} & \multirow{2}{*}{ Total } & \multirow{2}{*}{$\begin{array}{c}\text { Percentage } \\
\text { by } \\
\text { Respondent } \\
(N=172)\end{array}$} \\
\hline & 1 & 2 & 3 & 4 & 5 & & \\
\hline \multicolumn{8}{|l|}{ Top Five Most Pressing Issues } \\
\hline Too much paperwork & 48 & 28 & 25 & 23 & 9 & 133 & $77.33 \%$ \\
\hline Issues related to discipline & 22 & 29 & 23 & 27 & 27 & 128 & $74.42 \%$ \\
\hline $\begin{array}{l}\text { Insufficient opportunities for appropriate staff } \\
\text { development }\end{array}$ & 11 & 18 & 21 & 14 & 12 & 76 & $44.19 \%$ \\
\hline Lack of focus on the mental health needs of students & 11 & 19 & 20 & 12 & 12 & 74 & $43.02 \%$ \\
\hline Difficulty in obtaining positive parent support & 9 & 7 & 14 & 25 & 19 & 74 & $43.02 \%$ \\
\hline \multicolumn{8}{|l|}{ Additional Pressing Issues } \\
\hline Inadequate community-based support for students & 7 & 12 & 20 & 12 & 18 & 69 & $40.12 \%$ \\
\hline Resistance from others when trying to do inclusion & 9 & 17 & 8 & 16 & 14 & 64 & $37.21 \%$ \\
\hline Concern for physical safety & 12 & 9 & 8 & 3 & 9 & 41 & $23.83 \%$ \\
\hline $\begin{array}{l}\text { Poor physical facilities designed to meet students' } \\
\text { needs }\end{array}$ & 8 & 9 & 5 & 7 & 5 & 34 & $19.77 \%$ \\
\hline Management of the work by para-educators & 2 & 1 & 7 & 14 & 9 & 33 & $19.19 \%$ \\
\hline $\begin{array}{l}\text { Insufficient diversity among faculty based on } \\
\text { population served }\end{array}$ & 3 & 6 & 3 & 4 & 9 & 25 & $14.53 \%$ \\
\hline Fear of being furloughed from position & 2 & 6 & 6 & 3 & 6 & 23 & $13.37 \%$ \\
\hline Limited diversity among student body & 2 & 1 & 3 & 3 & 3 & 12 & $6.98 \%$ \\
\hline Other & 26 & 9 & 6 & 2 & 9 & 52 & $30.23 \%$ \\
\hline
\end{tabular}


Issues related to discipline was ranked as the second overall major issue faced by educators in their work assignment ( $\mathrm{n}=128 ; M=74.42 \%$ ). Insufficient opportunities for staff development was the third highest ranked concern identified ( $\mathrm{n}=76 ; M=44.19 \%)$ with the majority listing it as their second $(\mathrm{n}=18)$ or third $(\mathrm{n}=21)$ greatest concern. Tying for fourth and fifth most pressing issues identified were lack of focus on the mental health needs of students (n $=74 ; M=43.02 \%)$ and difficulty in obtaining parental support $(\mathrm{n}=74 ; M=43.027 \%)$. A lack of focus on mental health needs was selected the most as respondents' second $(\mathrm{n}=19)$ and third $(\mathrm{n}=20)$ pressing issue. Difficulty in obtaining positive parental support was selected as the fourth $(n=25)$ or fifth $(n=19)$ most pressing problem. The survey allowed respondents to write-in other concerns. Table 3 provides a myriad of additional concerns voiced by participants.

Table 3. Examples of Write in Comments from Others Category

\section{Respondents' Perceptions of Other Problems}

Not enough staff to cover all the needs

Administration (e.g., administrative respect, administrators are so out of touch with real student needs, lack of any positive support by administrators, lack of training on students with severe disabilities)

Money for purchasing hands-on real-life experiences

Class size (e.g., too many students in classes, too large for safety)

Too many tasks assigned simultaneously

Teacher evaluation system (e.g., has been set up so that we all fail)

Political policy counter to effective education

Not enough time (e.g., insufficient prep time when teaching 3 or more grades; to do what is expected in our "Duty

Day"; inadequate time to collaborate on a daily basis to meet planning for individual student needs!)

Lack of clear vision for student behavior

Very limited opportunities to fully develop programming and implementation skills to support remediation in students grades 4-HS and time/place to implement and operate

Forcing staff to take on positions

Lack of consistency

Communication (e.g., between campus and district level)

Para educators (e.g., pulled to cover extra duties and other classes, need training)

Testing (e.g., too many instructional days lost to state-mandated testing)

No support from district to develop programs to help at risk SPED students

Lack of knowledgeable and ethical central staff

Lack of interventions or support of interventions

Respondents' Perceptions of Other Problems

Too many students assigned to one teacher

Lack of high-level teaching across general education subject matters

Not enough staff directly working with students

General education reluctant to work with difficult students

Overuse of whole staff meeting with poor management

Help for students with disabilities

Inadequate Special Education Department support

High numbers of students with high needs 


\section{Discussion}

As we reflect on the outcomes from this pilot study, it is acknowledged that the responses may not be unique to working with challenging behaviors, but may be common for most educators working in the schools. However, by design, we focused on perceptions of educators who work specifically with students with challenging behaviors. Literature related to suggestions for managing asynchronous student behaviors abound, but these suggestions are often based on what authors perceive about challenging behaviors in the classroom (e.g., Dhaliwal, 2013; Kern, White, \& Gresham, 2007), and do not necessarily reflect the problems educators actually face in their day-to-day interactions in their educational communities.

Professional competence of educators is one aspect vital to the improvement of education (Lingam, 2012); therefore, preparation programs must be aligned with emerging changes and effective practices. Overall, respondents in the current study reported their professional preparation regarding their work with students with challenging behaviors to be average, yet their perception of being able to effectively educate students with challenging behaviors was somewhat above the mean. Allen (2003) reviewed 92 studies examining teacher preparation programs. In Allen's The Education Commission of States report found there is limited research support to conclude that pedagogy preparation significantly contributes to effective teaching; however, Allen cautions readers to keep in mind the limited amount of research around teacher preparation and believes there should be a renewed effort to garner more and better research.

Not surprisingly, too much paperwork was listed as a problem by the largest number of study respondents. A common concern among educators for many years, the paperwork issue continues to be viewed as a significant deterrent to quality instructional time and a contributor to teacher shortages, especially in high risk schools (Bunden, 2016; Rethink, 2015; Samuels, 2016; Vilson, 2016). Unfortunately, despite acknowledging the problem, little, if any, success in finding effective alternatives has been forthcoming, especially in providing quality services to students at high risk or who present challenging behaviors.

Issues related to discipline was the second major problem faced by study respondents, yet, they viewed themselves as being able to effectively work with students with challenging behaviors. They did, however, rate their professional preparation to be below the mean in implementation of classroom behavioral strategies which indicates that greater attention needs to be given to behavioral interventions and management strategies in professional preparation programs.

Respondents in the present study ranked insufficient time to participate in professional development activities as the third highest of five as a pressing issue faced. Continuous professional development is important for educators as it can, when planned and implemented correctly, enhance teacher quality and ultimately impact student learning. As further support for more professional development opportunities, Yates (2007) found teachers rated professional learning activities higher when the activities were directly related to their work rather than more generalized, non-specific topics. Moreover, teachers in the Yates' study preferred longer courses because they were perceived to be more applicable. Further, Desimone (2011) analyzed research on professional development and found (a) content focus, (b) active learning, (c) coherence, (d) duration, and (e) collective participation to be features of effective professional development.

Educators' perceptions of the school climate are greatly influenced by their administrators' leadership (Hardman, 2011; Somech \& Wenderow, 2006). In the current study, respondents' perceptions of their schools' leadership were below average to slightly above average. Although respondents believed their principals' overall leadership and support were average, they rated them as below average in providing an efficient framework addressing various tasks (e.g., paperwork, discipline, collaboration) required of them.

Today, schools operate in complex environments. There are many demands to meet external (e.g., state mandates, testing, excessive administrative meetings) and internal (e.g., time constraints, parental involvement) requirements while creating a positive learning environment in which teachers feel supported and students are successful. Ismail (2012) found that teachers value administrators who make consistent decisions while considering opinions of others. Hardman (2011) suggested that a teacher-focused administrator leads the school by building positive teacher abilities resulting in an increase in student achievement.

Respondents in the current study indicated their ability to collaborate with other educators and parents was about average. However, they cited difficulty in obtaining positive parental support and cooperation. Often educators erroneously believe the lack of parental participation is synonymous with the lack of interest or concern about their children's academic and social success. It is important to be cognizant that there may be numerous reasons for the 
parents' actions which may include (a) comfort level of parents in the school setting (Staples \& Diliberto, 2010), (b) employment circumstances (Green, Walker, Hoover-Dempsey, \& Sandler, 2007), and (c) cultural differences. Since student achievement is a positive outcome of collaborating with others, educators must continue to strive to help overcome barriers that may impede educator-parent collaboration. In addition to student achievement, per DuFour et al. (2010), other positive outcomes of collaboration are that it promotes clarity regarding the school program, encourages consistency between home and school, and helps establish ownership and a viable curriculum.

A lack of focus on mental health needs was also selected within the top five list of concerns by study respondents. It is recognized that schools face inordinate pressure to ensure students pass mandated state exams; in turn, investing large amounts of money and time into tutoring (Bullock, Zolkoski, \& Estes, 2014) often at the expense of supporting other critical student needs. It is noteworthy, but too often unrecognized, there is a strong relationship between academic success and mental health. Since schools are an ideal setting for delivering mental health services, there needs to be community support to help obtain school-based mental health services allowing for students' mental health and academic needs to be met. The school system and community agencies working together can generates positive feelings within the community about what the schools are doing.

As noted, issues related to discipline was listed among the top five pressing issues for study respondents. al-marat (2011) emphasized that school administrators play a key role in student discipline. In further support of the current findings, in a survey of new teachers, Goodwin (2012) found classroom management to be a struggle. Similarly, Manna (2015) found support, discipline, and classroom management to be among the biggest challenges educators face. It is, therefore, incumbent on school systems to have consistent positive behavioral interventions and management plans which can enhance student development. Unfortunately, school personnel often resort to punitive rather than positive discipline measures (Zolkoski, Bullock, \& Gable, 2016). Positive behavioral interventions and supports (PBIS) provide a proactive schoolwide approach for supporting appropriate behaviors and creating a positive school environment (OSEP Technical Assistance Center, 2017). Moreover, school-based mental health is supported within PBIS to improve outcomes for children and youth.

\section{Limitations}

One limitation of the present pilot study is the sample size; although there were 172 study participants, having a larger and more diverse sample could have provided more information and allowed for generalizability. Most of the respondents were female which is consistent with the typical composition of education personnel in schools; however, male respondents may provide a different set of needs. The researchers relied on respondents' perceptions because it is not possible to verify the accuracy of individuals' responses due to the nature of studies relying on self-reported data. Furthermore, respondents' recollection of information or events may not be accurate due to the passage of time.

\section{Implications}

The current study provides a glimpse of current educators' perceptions of (a) their preparation programs, (b) school leadership, (c) encouragement to collaborate with others, and (d) current problems they face educating students. Findings from this pilot study support the importance of continuing research pertaining to the perceptions of teachers in regard to teachers' and administrators' preparation programs. Informing future practice may help ensure the success of educators; in turn, assuring success of students. It is anticipated that in the future, a similar study will be conducted with a larger and more diverse sample which may reveal a more comprehensive understanding of educators' perceptions. Further, it may be interesting to conduct an intercountry study to ascertain the areas of commonality. Additionally, a study asking more in-depth questions may also further our understanding of educators' perceptions which may impact future practice. Although there are limitations associated with a preliminary study, we believe the findings of the current investigation address important issues regarding teachers' perceptions of working within the school system and may serve as a catalyst for a larger investigation.

\section{Concluding Statements}

There are many elements impacting the quality of instruction and educational experiences of today's children and youth. Collaborative dialogue between all educators (e.g., school administrators, classroom teachers, other school service providers) and parents is important to ensure student success. Each entity has a definitive role in accomplishing the mission of educating all students. Although this pilot study has certain limitations, the findings address important issues regarding educators' perceptions about providing services to students with challenging 
behaviors within the school system and may serve as an impetus for further research.

\section{References}

Al-amarat, M.S. (2011). The classroom problems faced teachers at the public schools in Tafila Province, and proposed solutions. International Journal of Educational Science, 3(1), 37-48.

Allen, M. (2003). Eight questions on teacher preparation: What does the research say? Education Commission of the States. Retrieved from www.ecs.org/tpreport

Beijaard, D., Verloop, N., \& Vermunt, J.D. (2000). Teachers' perceptions of professional identity: An exploratory study from a personal knowledge perspective. Teaching and Teacher Education, 16, 749-764. https://doi.org/10.1016/S0742-051X(00)00023-8

Brook, L., Sawyer, E., \& Rimm-Kauffman, S.E. (2007). Teacher collaboration in the context of responsive classroom approach. Teachers and Teaching: Theory and Practice, 13(3), 211-245. https://doi.org/10.1080/13540600701299767

Bullock, L. M., Zolkoski, S. M., \& Estes, M. B. (2015). Meeting the mental health needs of children and youth: Using evidence-based education worldwide. Journal of Emotional and Behavioural Difficulties, 20(4), 398-414. https://doi.org/10.1080/13632752.2015.1027631

Bunden, J. (2016). After 25 years, this teacher says it's all the paperwork that made him quit. Retrieved from http://www.npr.org/sections/ed/2016/09/04/485838588/after-25years

Center for Public Education. (2005). Teacher quality and student achievement: Research review. Retrieved from www.centerforpubliceducation.org

Coleman, C. (2005). Teacher perceptions of administrative leadership styles and schools as professional learning communities. (Unpublished doctoral dissertation), University of New Orleans, New Orleans, Louisiana. Retrieved from: $\mathrm{http}: / /$ scholarworks.uno.edu/cgi/viewcontent.cgi?article=1290\&context $=\mathrm{id}$

Desimone, L. M. (2011). A primer on effective professional development. Phi Delta Kappan, 92(6), 68-71. https://doi.org/10.1177/003172171109200616

Dhaliwal, M. (2013). Teacher perceptions and management of challenging student behaviours in primary school classrooms. Unpublished Master's Thesis, Unitec Institute of Technology, Auckland, New Zealand.

DuFour, R., DuFour, R, Eaker, R., \& Many, R. (2010). Learning by doing: a handbook for professional learning communities at work. Bloomington, IN: Solution Tree.

Goldstein, A. (2015). Teachers' perceptions of the influence of teacher collaboration on teacher morale. (Unpublished doctoral dissertation), Walden University, Minneapolis, MN.

Goodwin, B. (2012). Research says / new teachers face three common challenges. Educational Leadership, 69(8), 84- 85 .

Green, C. L., Walker, J. M. T., Hoover-Dempsey, K. V. \& Sandler, H. M. (2007). Parents' motivation for involvement in children's education. Elementary School Journal, 91(3), 532-44.

Guglielmi, R. S. (2008). Native language proficiency, English literacy, academic achievement, and occupational attainment in limited English proficient students: A latent growth modeling perspective. Journal of Educational Psychology, 100, 322-342. https://doi.org/10.1037/0022-0663.100.2.322

Hagelman, E. (2013). Special education co-teachers' perceptions: Collaboration, involvement in instruction, and satisfaction. (Unpublished doctoral dissertation), University of New Orleans, New Orleans, LA.

Hamdallah, N. (2005). Problems in classroom management as perceived by the class teachers in UNRWA schools in Jordan. (Unpublished master's thesis), Jordan University, Amman.

Hang, P. (2011). Teachers' perceptions of their principals' leadership capacities. Retrieved from http://www.academia.edu/4338814/TEACHERS_PERCEPTIONS_OF_THEIR_PRINCIPALS

Hardman, B. K. (2011). Teachers' perception of their principal's leadership style and the effects on student achievement in improving and non-improving schools. (Unpublished doctoral dissertation, University of South Florida, Tampa, FL.

Heckathorn, D. D. (1997). Respondent-driven sampling: A new approach to the study of hidden populations. Social 
Problems, 44(2), 174-199. https://doi.org/10.2307/3096941

Iordanides, G., Lazaridou, A., \& Babaliki, M. (2011). The principal's role in achieving school effectiveness. Retrieved from: http://www.icsei.net/icsei2011/Full\%20Papers/0043.pdf.

Ismail, M. R. (2012). Teacher perceptions of principal leadership styles and how they impact teacher job satisfaction. (Unpublished doctoral dissertation), Colorado State University, Fort Collins, CO.

Kern, L., White, G.P., \& Gresham, F. (2007). Educating students with behavioral challenges. Washington, DC: National Association of Elementary School Principals. Retrieved from www.naesp.org

Kursunoglu, A., \& Tannogen, A. (2009). The relationship between teachers' perceptions towards instructional leadership behaviors of their principals and teachers' attitudes towards change. Procedia - Social and Behavioral Sciences, 1(1), 252-258. https://doi.org/10.1016/j.sbspro.2009.01.046

LaRocque, M., Kleiman, I., \& Darling, S. M. (2011). Parental involvement: The missing link in school achievement. Preventing School Failure, 53(3), 115-122. https://doi.org/10.1080/10459880903472876

LaVotte, O. K., \& Karst, R. (n.d.). Teacher perceptions of leadership behavior and change within their schools. National Forum Journal. Retrieved from http://www.nationalforum.com/Electronic\%20Journal\%20Volumes/LoVette,\%20Otis\%20K.\%20Teacher\%20P erceptions\%20of\%20Leadership\%20Behavior\%20and\%20Changefp\%20Within\%20Their\%20Schools. pdf

Leonard, R. D. (2013). Factors that influence teachers' perception of school climate at one metro Atlanta high school. (Unpublished Doctoral Dissertation). Clark Atlanta University, Atlanta, GA.

Lingam, G. (2012). Beginning teachers' perceptions of their training programme. Creative Education, 3(4), 439-447. Doi:10.42236/ce2012.34068

Manna, R. (2015). What big challenges do new teachers face? Retrieved from: http://www.scholastic.com/teachers/article/what-big-challgenges-do-new-teachers-facel

McCann, G.D. (2011). A study to examine teacher perceptions of leadership characteristics that middle school principals should have to be an effective instructional leader. (Unpublished doctoral dissertation). East Tennessee State University, Knoxville, TN.

Mercurius, N. (n.d.). Teachers' perception of administrators who helped them promote learning. Retrieved from: http://files.eric.ed.gov/fulltext/ED492637.pdf

Methner, G. V. (2013). Perceptions of administrative support and follower readiness in middle school teachers. (Unpublished doctoral dissertation). Bowling Green State University, Bowling Green, $\mathrm{OH}$.

Moore, A. (2012). Problems teachers face in the classroom. Retrieved from http://www.ehow.com/info_7911351_problems-teachers-face-classroom.html

National Association of Elementary School Principals. (2013). Leadership matters. Retrieved from: http://www.naesp.org

National Center for Educational Statistics (2015). English language learners. Retrieved from: $\mathrm{http}: / /$ nces.ed.gov/programs/coc/indicator_cgf.asp

Oppenheim, A. N. (1992). Questionnaire design, interviewing and attitude measurement. London: Pinter.

OSEP Technical Assistance Center. (2017). Positive behavioral interventions and supports. Retrieved from: www.pbis.org

Paolini, A. (2015). Enhancing teaching effectiveness and student learning outcomes. Journal of Effective Teaching, 15(1), 20-33.

Pennsylvania Partnerships for Children. (2011). Teacher effectiveness and student achievement. Retrieved from: www.partnerships.org

Phillips, J. (2013). Why should I go? Florida teachers' perceptions of value in ELL professional development. (Unpublished doctoral dissertation), Florida State University, Tallahassee, FL. http://diginole.lib.fsu.edu/etd/8620

Powers, K. (2012). New teachers' perceptions of their preparation. A follow-up study. (Unpublished doctoral dissertation), Iowa State University, Ames, IA.

Rand Corporation. (2017). Teachers matter: Understanding teachers' impact on student achievement. Retrieved 
from: https://www.rand.org/pubs/monograph_reports/MR1382.html

Rethink. (2015). 3 problems facing special education teachers in today's schools. Retrieved from: http://www.rethinkrethink.com/blog/2015/11/20/3-problems-special-education-teachers-face/

Richardson, M. D., Lane, K.E., \& Flanigan, J.L. (1996). Teachers' perceptions of principals' attributes. The Clearing House, 69(5), 290-292. https://doi.org/10.1080/00098655.1996.10114321

Samuels, C. (2016). Is special education paperwork really a problem? Retrieved from http://blogs.edweek.org/edweek/speced/2016/02/special_education_paperwork_burden.html

Sharma, S. (2005). Multicultural education: Teachers' perceptions and preparation. Journal of College Training and Learning (TLC). Retrieved from: http://www.cluteinstitute.com/ojs/index.php/TLC/article/view/1825

Shrestha, L. B., \& Heisler, E. J. (2011). The changing demographic profile of the United States. Washington, DC Congressional Research Service. Retrieved from: www.fas.org/sgp/crs/misc/RL32701.pdf

Sipes, E. J. (2014). Middle school teachers' perceptions of administrator influence on teaching and learning. Retrieved from: SipesMidSchTea.pdf(/xmlui/bitstream/handle/10355/43714/SipesMidSchTea.pdf?sequen ce=1

Somech, A., \& Wenderow, M. (2006). The impact of participative and directive leadership on teachers' performance: the intervening effects of job structuring, decision domain, and leader-member exchange. Educational Administrative Quarterly, 42(5), 746-772. https://doi.org/10.1177/0013161X06290648

Staples, K. E., \& Diliberto, J. A. (2010). Guidelines for successful parental involvement: Working with parents of students with disabilities. TEACHING Exceptional Children, 42(6), 58-63. https://doi.org/10.1177/004005991004200607

The Take Away. (2012). The biggest issues facing public schools according to teachers. Retrieved from: http://www.thetakeawya.org/story/240519-teachers-weigh-biggest-issues-facing-public-school

United States Census. (2016). Census regions. Retrieved from: https://www.census.gov/geo/reference/gtc_census_divreg.html

Vilson, J. (2016). What do you mean, excessive paperwork? Retrieved from: http://thejosevilson.com/what-do-youmean-excessive-paperwork?

Waldron N. L., \& Mclesky, J. (2010). Establishing a collaborative school culture through comprehensive school reform. Journal of Educational and Psychological Consultation, 20, 58-74. https://doi.org/10.1080/10474410903535364

Watkins, N.M., \& Lindahl, K. M. (2010). Targeting content area literacy instruction to meet the needs of adolescent English language learners. Middle School Journal, 4(3), 23-32. https://doi.org/10.1080/00940771.2010.11461718

Yates, S.M. (2007). Teachers' perceptions of their professional learning activities. International Education Journal, $8(2), 213-221$.

Zolkoski, S. M., Bullock, L. M., \& Gable, R. A. (2016). Resilience: Perspectives of graduates from alternative education programs. Preventing School Failure, 60(3), 231-243. https://doi.org/10.1080/1045988X.2015.1101677 